\title{
The Sarmatian vertebrates from Draxeni (Moldavian Platform)
}

\section{Vlad CODREA ${ }^{* *}$ \& Laurenţiu URSACHI ${ }^{2}$}

${ }^{1}$ Department of Geology-Paleontology, „Babeş-Bolyai“ University, Kogălniceanu 1, 400084 Cluj Napoca, Romania

${ }^{2}$ Bârlad Museum, Natural Science Branch, 1 Vasile Pârvan Str., 731050 Bârlad, Romania.

Received July 2006; accepted April 2007

Available online xx September 2007

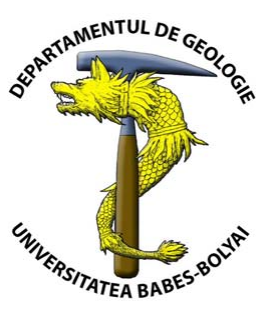

\begin{abstract}
Middle Miocene (Sarmatian) vertebrates had been unearthed at Draxeni (Vaslui district). The site is located in the northern area of the Moldavian Platform. There, the sand belonging to Şcheia Formation (Bessarabian) is mined in a restricted open pit. This sand is related to a littoral environment (shoreface and foreshore). Some of its levels are rich in mollusc debris. Vertebrate remains, carried into the Bessarabian brackish basin are present too, but in smaller amounts. Mastodon, rhinoceros, hipparionine, tortoise remains had been collected there over several years. All teeth and bones are isolated and bear the marks of intensive rolling by waves and currents. This assemblage is typical for the top of Bessarabian in Moldavia, i.e. soon after the first hipparionine invasion in this part of the Europe. This assemblage can be related to the base of MN 9 unit.
\end{abstract}

Key-words: Middle Miocene, Sarmatian, Moldavian Platform, vertebrate paleontology.

\section{INTRODUCTION}

The Moldavian Platform (i.e., the south-western sector of the East-European Platform or Subcontinent; Săndulescu, 1984) is well known for its widely exposed Sarmatian (Middle Miocene) formations.

There, for most of the Middle Sarmatian (Bessarabian) deposits belong to a brackish basin related to the Paratethys Sea (Steininger et al., 1985; Rögl, 1999). From the Late Sarmatian (Khersonian), land tendencies became more and more accentuated, mainly in the western areas of the platform (Jeanrenaud, 1971; Grasu et al., 2002).

Recent paleontological studies focused on the Bessarabian molluscs originating from various outcrops located west of the Prut River outnumbered by far those concerning other groups, for example the vertebrates. It is also true that the latter are rather rare and were always collected through fortuitous findings and not from systematic diggings. Usually, Bessarabian vertebrates are represented by disconnected teeth and bones, carried by the river streams into the brackish sedimentary basin. Such hydrographic system occurred immediately after the Moldavian tectogenesis which erected the last major nappe belonging to the Eastern Carpathian Moldavides, the Subcarpathian Nappe (Săndulescu, 1994).

Recently, sand quarrying at a small open pit located at Draxeni (Vaslui district; Fig. 1) unearthed several reptile and mammal teeth and bones, originating from the uppermost part of the Bessarabian sedimentary succession. Such fossils had not previously been reported from Draxeni.

\section{GEOLOGICAL SETTING}

The open sand pit named "La Nisipărie" at Draxeni is located on the left bank of Bolaț River at the base of the hill slope, at an altitude of 159-167 $\mathrm{m}$. The pit exposes an $8 \mathrm{~m}$ succession of lumachelle sand, greenish clay sand and silts.

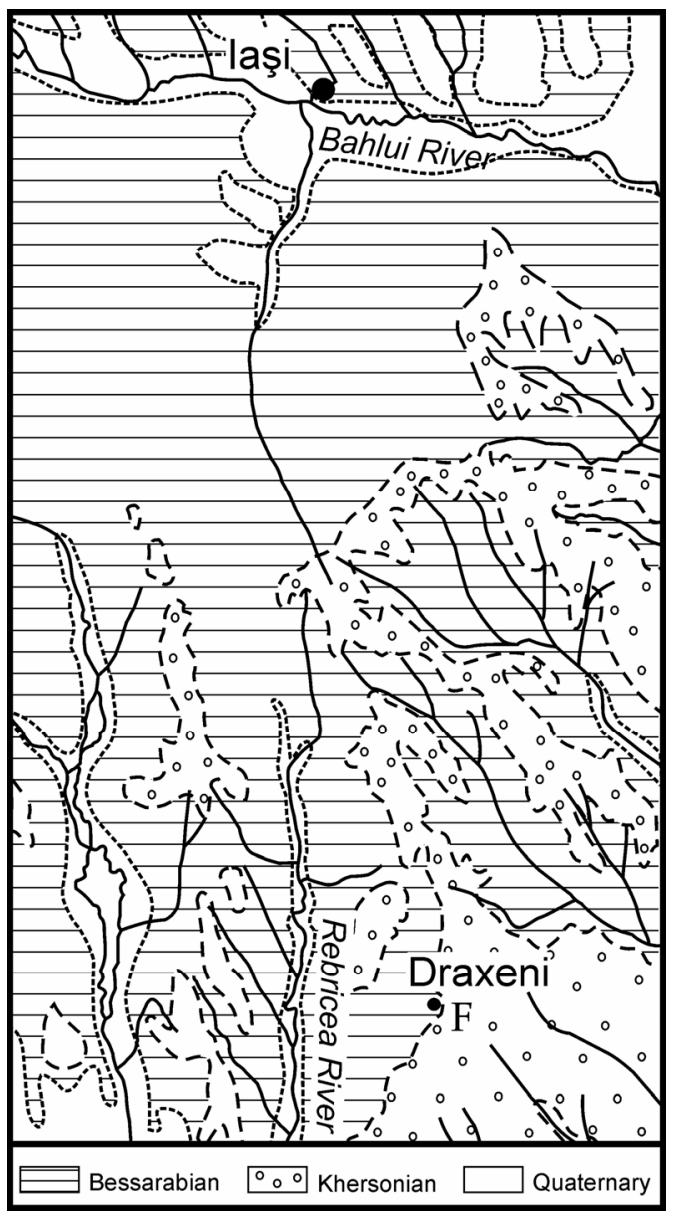

Fig. 1. Location of Draxeni locality on the geologic map (According to Jeanrenaud, 1971; modified). 
These rocks belong to the Şcheia Formation (David, 1922; Jeanrenaud, 1971), i.e., the last Bessarabian level in the Modavian Platform (Ionesi, 1994). Above, one can observe the Meotian sand attributed to the Păun Formation (Jeanrenaud, 1961; also known as Balta-Păun Formation (Ionesi and Ionesi, 2004). However, the boundary between these two formations is not clearly exposed at Draxeni, due to the soil and slope debris covering.

According to Ionesi and Ionesi (2004) the Şcheia Formation could be divided into two members: Pietrăria (lower) and Muncelu (upper). The first would include oolitic limestone with Mactra (Podolimactra) podolica EICHWALD 1853. In the second, arenite dominates, with different Mactra species and subspecies, Plicatiforma, Tapes etc., with a notable diversity of species (Ionesi and Țabără, 2004).

At Draxeni, the basal member - if present - does not crop out. In these circumstances, the sand in the open pit could be related to the Muncelu Member.

The sand consists of angular and subangular white quartz grains. Subordinate muscovite is present, along with rare biotite spangles. In some sectors, there is lumachelle sand with a high concentration of small comminuted mollusc and ostracod shell fragments. Complete mollusc shells are rare. However, we observed some Mactra (Sarmatimactra) fabreana D’ORBIGNY 1844, Mactra (Podolimactra) podolica, Dorsanum duplicatum duplicatum (SOWERBY 1829), and Gibulla sp. shells. Towards the base of the outcrop, it is fine to medium sand, medium sorted, sometimes rich in sandy clay intra-formation reworked clasts.

On the basis of these features, the lithological succession at Draxeni open-pit could be interpreted as representing the shoreface $>$ foreshore environments, i.e., a regressive evolution (Fig. 2). Energy of the environment was obviously high, the teeth and bones bearing marks of rolling by waves and currents before their burial. The remains are always isolated, no anatomical connection being reported until now.

The vertebrate fossils are curate at the Natural Science Branch, Bârlad Museum.

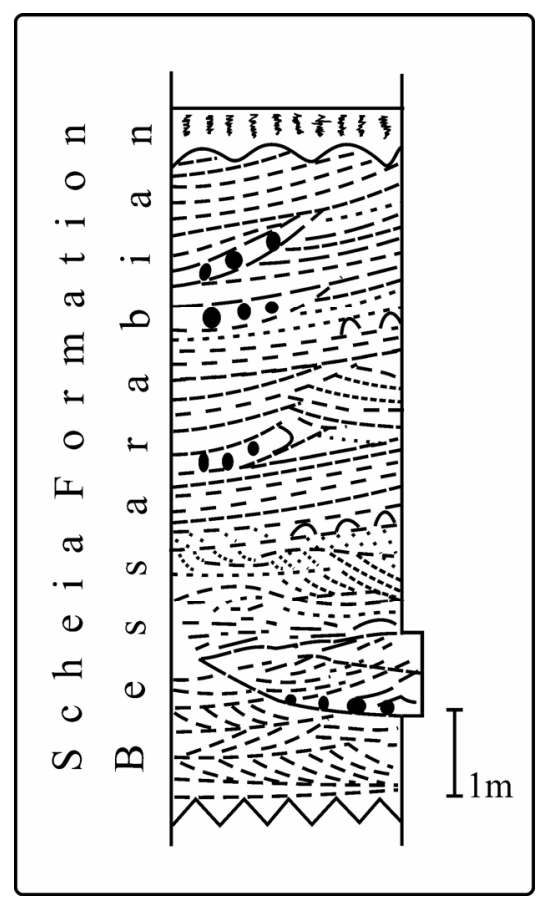

Fig. 2. Lithologic log of Draxeni outcrop.

\section{PALEONTOLOGY}

Class Reptilia LAURENTI 1768

Order Chelonii BRONGNIARD (LATREILLE) 1800

Family Testudinidae BATSCH 1788

Testudinidae indet. (small to medium size)

Pl. I, Figs. 1-7

\section{Material}

Right PL 3, left PL 6, ? PL, ? hypoplastron fragment.

\section{Measurements (mm)}

PL 3: L - 51.3 (without articular apophysis); 1 proximal - 24.1; 1 distal - 32.0; proximal thickness - 6.0; distal thickness -16.7

Several isolated tortoise carapace and plastron fragments have been collected at Draxeni. All bones show heaving rolling marks passed before burial.

PL 3 belonged to a mature individual, showing features very close to Testudo graeca ibera. The areolar sculptures seem to be missing, but the bone surface is strongly eroded.

In Pe 6 the lateral margins show concave lines. It is possible that this bone belonged to a sub-adult individual.

Two other fragments are too incomplete for study.

Class Mammalia LinNAEUS 1758

Order Proboscidea ILLIGER 1811

Genus Tetralophodon FALCONER 1857

Tetralophodon longirostris (KAUP 1832)

Pl. II, Figs 1-3

\section{Material}

Right M3.

\section{Measurements (mm)}

L - 156.0; 1 max.- 83.5 (2); 1 min. - $51.0_{(5)}$; H max. - 53.0 (3); $1 / \mathrm{L}$ index $-0.54 ; \mathrm{L} / 1$ index $-1.87 ; \mathrm{H} / \mathrm{L}$ index -0.34

The molar crown is nearly complete, and includes most of the roots. The crown is slightly broken in the mesiovestibular area, almost half of the ectoloph halfloph being damaged, probably when the tooth was extracted from the rock matrix.

The M3 consists of five transverse lophs. Only the first loph is slightly worn by attrition, more advanced on the pretrite half ridge (entoloph). The others lophs are pristine. The outline in occlusal view is oval elongate, unequal. The exterior side is convex, the lingual one is more or less straight. The pressure mark for M2 can be observed on the anterior margin on the cingulum. The maximum width is in the anterior half of the tooth. The second loph is wider than the others. The first two lophs are straight. The next ones are "V"-shaped, with the convexity toward the mesial side. Both buccal and lingual slopes descending from the top crests towards the crown base are equally bold. The median sulcus is clear forming a jagged line. The first syncline separating the lophs is blocked by the close juxtaposition of the posterior crescentoid 1 and the anterior crescentoid 2. The following synclines are not obstructed. Cement is present in the synclines, mainly on their buccal sides. There is no internal cingulum. In the openings of the transverse 
synclines there are components of a discontinuous external cingulum.

The tooth pattern in simpler than other discoveries of Tetralophodon from Western Europe (e.g. Portugal, Bergounioux et al., 1953; Antunes and Mazo, 1983). It resembles rather the specimens illustrated by Schlesinger (1922) from Hungary and Austria. The evolutionary tendency of the species was towards increase of cheek teeth size (Göhlich, 1999). The tooth dimensions of the Draxeni fossil seem to indicate a primitive representative, belonging to the primary stock. This is agrees well with the age of the deposits which yielded the fossil.

Order Perissodactyla OwEN 1848

Genus Aceratherium KAUP 1832

Aceratherium incisivum KAUP 1832, 1834

Pl. III, Figs. 1-7

\section{Material}

Left P4; left M2 fragment; right p3; left ? Mc V; lower ? premolar, abraded by rolling.

\section{Measurements (mm)}

P4: L - 43.3, $1_{\text {anterior }}$-51.9, $1_{\text {posterior }}$ 49.2; M1: L - 48.0; p3: L - 37.7, 1 anterior - 23.4, 1 posterior - 25.1; ? Mc V: Maximal distal transverse diameter: 23.0; Articular distal transverse diameter: 22.0; Antero-posterior transverse diameter: 29.0

All the rhinoceros teeth were found isolated, in different parts and levels of the sand open pit. All belong to mature individuals.

P4 preserves its entire crown. The roots had been broken probably when the tooth was extracted from its rock matrix. The external roots are separated and the internal ones are fused. The ectoloph is almost flat. However, one can observe an extremely attenuated, indistinct metacone fold, as well as a large paracone fold, which disappears towards the crown base. A large and simple crochet is present. Crista is practically absent but a closer look reveals, however a slightly wavy enamel in this area. The anticrochet is absent, as is the protocone constriction. A strong internal cingulum is present, discontinuous in the protoloph termination area. The tooth is devoid of an external cingulum. The protoloph is obviously longer than the metaloph. Between the protoloph and metaloph there is a small enamel pillar connecting the two lophs towards the end of the transverse valley, obstructing its opening. Due to this feature, the premolar is semi-molariform.

The post-fossette has an elongated triangular outline, its depth being somewhat greater than the one of the transverse valley.

Only a M1 fragment is available, preserving the ectoloph and the median valley. The rest of the crown was broken and the roots are missing. It originates from an adult individual. The ectoloph is fairly wavy, with blunt and wide paracone fold, attenuating towards the crown base. A slight metacone bulge is present. An undivided crochet is present, without crista and antecrochet. The protocone constriction is marked. It seems that the internal cingulum was discontinuous, with a residue closing the opening of the median valley. A strong external cingulum can be observed, mainly on the distal half of the ectoloph.
The p3 preserve only the crown without roots, which were broken before burial, when the tooth was rolled by waves. Strong pressure marks can be observed mesially and distally. The occlusal attrition is advanced. Both transverse valleys are "V" shaped, the anterior one being the shorter of the two. The difference between the levels of these valleys is high. A strong uninterrupted internal cingulum is present, as well as an external one which is stronger on the distal prism.

Only a distal fragment documents the ? Mc 5. According to Guérin (1980), this bone is poorly known in A. incisivum and the biometric data available are extremely scarce.

Genus Hippotherium VON MEYER 1829

Hippotherium sp. (cf. Hippotherium primigenium VON MEYER 1829)

Pl. IV, Figs. 1-3

\section{Material}

Right M3

\section{Measurements (mm)}

L ectoloph - 23.7; 1 - 19.0; L protocone - 6.0; 1 protocone -3.2 ; H: 46.0

The unique tooth documenting the presence of tridactyle horses in this assemblage shows the same rolling marks as the other teeth and bones. For this reason a part of the cement once covering the tooth crown was eroded off. In this manner, the measurements are probably smaller values than the initial ones. The protocone is ellipsoidal elongate, twice as long as large. The fossettes have high enamel plication mainly in the prefossette and the anterior margin of the postfossette.

The tooth indicates a medium sized Hippotherium.

Ord. Artiodactyla OwEN 1848

? Lagomerycinae CRUSAFONT, 1952 (Lagomeryx flerovi LUNGU 1968 - size)

Pl. IV, Fig. 4

\section{Material}

Tibia diaphysis fragment.

\section{Measurements (mm)}

Mid-shaft antero-posterior diameter - 9.7; Mid-shaft transverse diameter -10.5

Both epiphyses have been broken. The bone has a typical patina indicating rolling before burial, as for the other fossils from the same site.

The tibial diaphysis fragment has a triangular mid-shaft outline. The posterior side is very flat. Above the distal end one can observe an unusual dilatation, probably of posttraumatic origin.

The size of the bone accords well with the dimensions indicated by Lungu (1984) for L. flerovi.

\section{DISCUSSION}

Representatives of Protestudo are reported only from the left bank of the Prut River (Moldova Republic) either from 
upper Bessarabian or Khersonian deposits (Lungu, in Ionesi et al., 2005). However, Protestudo genus which has as typespecies Testudo bessarabica RIABININ 1918 from the Late Miocene from Taraklia, or this species is now considered as de Lapparent et al. (2006) as an Agrionemys representative. Extant Testudo graeca grace, which could be a descendant of the ancient forms of the Testudinidae from this area, has a natural habitat which includes semi-arid scrub and Mediterranean forest, to the verges of semi-desert. This habitat is influenced by seasonal changes in vegetation. Usually, in extant habitats, one can find this tortoise in environments such as garigue, maquis or Mediterranean forests, in arid and warm areas.

The Draxeni mastodon belongs to the so-called "tetralophodont gomphotheres", representing a distinct subfamily of uncertain status (Shoshani and Tassy, 1996; Göhlich, 1999) integrating representatives derived from Gomphotheriidae ancestors.

According to Gaziry (1997), T. longirostris is recorded between MN 8 and MN 11 units. However, Mazo (1996) considers a wider species range, between $\mathrm{MN} 7+8$ and $\mathrm{MN}$ 12. Lungu and Obada (2001) support a similar opinion. They affirm that at the beginning of the Vallesian $T$. longirostris was coeval with Gomphotherium angustidens.

This mastodon is a characteristic marker of the Hipparion fauna throughout Moldavia. From Moldova Republic, it is reported from several localities such as: Otovasca, Pocşeşti, Taraclia, Drăguşeni, Grebenichi, Novoelizavetovka etc. (Lungu and Obadă, 2001). In contrast, the species is considerably rare from the Prut right bank areas and it is seldom reported from Romania. Saraiman (1966) mentioned a mandible from the Şişcani Meotian, near Huşi. Later, Jurcsák (1973, 1983) assigned a tusk fragment from Derşida (Sălaj District, NW Transylvania) and two molars from Dijir (Bihor District) to this species. He also mentioned a specimen transitional to Anancus arvernensis from Tătăruş (Bihor District). Due to its scarce mammal assemblage, Dijir cannot be related to an adequate MN unit. Derşida belongs to MN 13 (Codrea et al., 2002) and the presence of $T$. longirostris there, seems unlikely.

A. incisivum is a very common rhino in the Vallesian and Turolian mammal assemblages of Romania (Codrea, 2000). It is known mainly from MN 9-MN 11, but in other parts of Europe it is also known from MN 9-MN 13 (Guérin, 1980). In some sites in Romania it is associated either with Choerolophodon pentelici (Reghiu, Bacău, both MN 10; Rădulescu et al., 1995) or with T. longirostris (Derna).

The majority of localities where A. incisivum has been found (Codrea, 2000) indicate a preference for a habitat dominated by forests, near the borders of rivers, lakes and swamps. However, open areas covered by grass should also exist and perhaps a savanna-like environment could be its habitat in certain periods, this kind of environment was rather specific for the Turolian representatives of this species.

The Middle Sarmatian hipparionines are a subject of debate throughout Europe, because they were the first invaders of the continent around $11.5+/-0.5 \mathrm{Ma}$ (Bernor et al., 1988) or slightly younger datum (Steininger et al., 1996). Some authors sought to describe several new species originating from the first hipparionine wave (e.g., Nikolov, 1971). In contrast, there are opinions that Hippotherium primigenium was possibly the only species appearing in Europe at first (Forsten, 1978; Holec, 1981). Bernor et al.
(1996) point out that the first European representatives belong to the so-called "Hippotherium primigenium Complex", with $H$. primigenium I stage as representative.

In Moldova, following Gromova's (1952) ideas, Macarovici $(1967,1973)$ affirmed that $H$. primigenium does not occur, being replaced by other species. Later, in the Middle Sarmatian from the east side of Prut (Moldova Republic), Lungu (1984) defined a distinct species, Hipparion sarmaticum LUNGU 1984 as part of a faunal assemblage named Kalfa. The same equid species was later mentioned in the Middle Sarmatian of Romania as well as in the Repedea Formation (Codrea et al., 1992), from the Şcheia Formation (Lungu et al., 1993) and from the Bârnova-Muntele or Bohotin Formations (Cochior and Nechita, 1993). However, the last-mentioned is rather unclear as a „Hipparion” tooth was found at the base of the Bohotin outcrop. According to Ionesi et al. (2005) in the locality where the tooth was found, there are exposed three different formations, $i$. e., Bîrnova-Muntele, Bohotin and Balta-Păun. If the tooth really originates from BârnovaMuntele Formation, it means that it would be the oldest known Hipparion from Romania. However, it is worth mentioning that even Cochior and Nechiti (1993) expressed reticence concerning the exact stratigraphic location of the fossil. In spite of this incertitude, several subsequent citations refer to a certain position as well (e.g., Ionesi, 1994; Ionesi et al., 2005).

The Draxeni Hipparion cannot be assigned for instance to one or another of the mentioned species because of the scarcity of the material. However, it could be similar to the fossil hipparionine described as „H. sarmaticum”. Maybe, later revisions will prove whether $H$. sarmaticum is valid, because it is possible that this species is nothing else but a junior synonim of $H$. primigenium Bernor (written communication) think that $H$. sarmaticum is probably similar either to Hippotherium primigenium or Hippotherium intrans KRETZOI 1983.

For the robust lower Vallesian hipparionine, the environments also concern riparian forests (Koufos, 1986; Bernor et al., 1988), in a warm-temperate climate without a dry season. Țabără and Olaru (2004) and Țabără (2006) mentioned the presence of mesophytic forests with Quercus, Fagus, Ulmus, Carpinus, Castanea, Carya etc in the Late Bessarabian from Moldova, but also evidence the presence of open areas with grass documented by Chenopodiaceae and Gramineae. Swamps populated by Taxodiaceae, Myrica, Salix, Nyssa etc. were not absent. Earlier, this kind of environment had been outlined by Codrea et al. (1991) for the Repedea Limestone Formation (Bessarabian), a level located just below the Şcheia Formation.

The artiodactyls belonging to Lagomeryx are often recorded in the Sarmatian faunal assemblages from the left side of the Prut River, both in Kalfa and Varnița complexes (Lungu, 1984). L. flerovi is the characteristic species for each one. On the Romanian territory, this small herbivore is rare. However, Simionescu and Trelea (1991), reviewing an older finding (Macarovici and Paghida, 1966) from BaltaPăun Formation (Khersonian), assigned to this species a mandible fragment originating from Păun open pit. Due to the incomplete fossil we have from Draxeni one cannot specify the species, but one can however, presume that the tibia could belongs to L. flerovi. The environmental interpretation for this kind of Cervoidea is the same as for the other taxa already mentioned. 


\section{CONCLUSION}

As a whole, one can presume that the vertebrate fauna from Draxeni represents a mixture of several types of habitats, brought together by the fluvial transport. The Upper Bessarabian environments of Moldova should be perceived as varied, depending on each episode of the evolving paleogeography, related to its proximity to the boundary between land and brackish basinal environments. In such zones, a multitude of habitats could develop, each one hosting its own peculiar representatives.

This faunal assemblage from Draxeni can be correlated to the base of the MN 9.

Acknowlwdgements. We express our gratitude to Raymond Bernor (Howard University, Washington) for his help in obtaining several references related to Hipparioninae and for his opinions on the first representatives in Europe; special thanks to France de Lapparent (Muséum National d'Histoire Naturelle Paris), for her helpful references and discussions on the Testudinidae, as well as for her hospitality during the visit of one of us (C.V.) in Paris; Emanoil Ştiucă (Speleological Institute "Emil Racovitza" Bucharest) helped us in obtaining some references; same thanks to our colleagues and friends from Babeş-Bolyai University of Cluj-Napoca: Matei Vremir for his help related to the study of tortoises from Draxeni, Emanoil Săsăran for his contribution in interpreting the sedimentology data and last, but not least, special thanks to Cristina Fărcaş, always ready to give a helping hand.

Special thanks are addressed to an anonymous referent, for its contributions and for the patience to correct the English version of this text.

\section{R E F E R E N C E S}

Antunes, M.T., Mazo, A.V., 1983, Quelques mastodontes miocènes du Portugal. Ciências da Terra, 7: 115-128.

Bergounioux, F. M., Zbyszewski, G. \& Crouzel, F., 1953, Les mastodontes miocènes du Portugal. Mémoires des Services Géologiques du Portugal, Nouvelle Série, 1, 139 pp.

Bernor, R.L., Kovar-Eder, J., Lipscomb, D., Rögl, F., Sen, S. \& Tobien, H., 1988, Systematic, stratigraphic, and paleoenvironmental contexts of first-appearing Hipparion in the Vienna Basin, Austria. Journal of Vertebrate Paleontology, 8 (4): 427-452.

Bernor, R.L., Koufos, G.D., Woodburne, M.O. \& Fortelius, M., 1996, The Evolutionary History and Biochronology of European and Southwest Asian Late Miocene and Pliocene Hipparioninae Horses. In The Evolution of Western Eurasian Neogene mammal Faunas (R.L. Bernor, V. Fahlbusch, H.-W. Mittmann, Eds.), Columbia University Press, New York, p. 307-338.

Cochior, C., Nechita, L., 1993, Prezența lui Hipparion cf. sarmaticum LUNGU în Sarmațianul de la Bohotin. Studii şi cercetări de geologie, 38: 81-86.

Codrea, V., 2000, Rinoceri şi tapiri terțiari din România. Presa Universitară Clujeană, Cluj Napoca, 174 p.

Codrea, V., Brânzilă, M. \& Hosu, A., 1992, Environmental and stratigraphical significance of a "Hipparion" remain from the Repedea Limestone. Studia Universitatis Babeş-Bolyai, Geologia, 37 (2): 43-87.

Codrea, V., Fărcaş, C., Săsăran, E. \& Dica, P., 2002, Late Miocene mammal fauna from Derşida (Sălaj district) and its related paleoenvironment. Studia Universitatis BabeşBolyai, Geologia, Special Issue 1: 119-132.

David, M., 1922, Cercetări geologice în Podişul Moldovenesc. Anuarul Institutului Geologic al României, XIX: 69-219.

Forsten, A., 1978, A review of Bulgarian Hipparion (Mammalia, Perissodactyla). Géobios, 11 (1): 31-41.

Gaziry, W.A., 1997, Die Mastodonten (Proboscidea, Mammalia) aus Dorn-Dürkheim 1 (Rheinhessen). Courier Forschungs-Institut Senckenberg, 197: 73-115.

Göhlich, B.U., 1999, Order Proboscidea. In The Miocene Land Mammals from Europe (Rössner, G.E., Heissig, K., Eds.), Munchen, p. 157-168.

Grasu, C., Miclăuş, C., Brânzilă, M. \& Boboş, I., 2002, Sarmațianul din sistemul bazinelor de foreland ale Carpaților Orientali. Ed. Tehnică, Bucureşti, 407 p.

Gromova, V., 1952, Ghipparionî (rod Hipparion). Akademia Nauk SSSR, Trudî Palaeontolog. Institut, XXXVI, Moskwa, $478 \mathrm{p}$.

Guérin, C., 1980, Les rhinocéros (Mammalia, Perissodactyla) du Miocène terminal au Pléistocène supérieur en Europe Occidentale. Comparaison avec les espèces actuelles. Documents des Laboratoires de Géologie Lyon, 79 (1): 1-401.

Holec, P., 1981, Occurrences of Hipparion primigenium (H.v. Meyer, 1829) (Mammalia, Equidae) remnants in the Neogene of the West Carpathians (Czechoslovakia). Geologica Carpathica, 32 (4): 427-447.

Ionesi, L., 1994, Geologia unităților de platformă şi a orogenului Nord-Dobrogean. Ed. Tehnică, Bucureşti, $280 \mathrm{p}$.

Ionesi, B., Tabără, D., 2004, Faune de mollusques de la Formation de Şcheia (Plate-forme Moldave). Acta Palaeontologica Romaniae (Codrea V., Petrescu I., Dica, P., Eds.), IV: 163-174.

Ionesi, L., Ionesi, B., 2004, Formaţiunea de Repedea şi variațiile sale litologice (Platforma Moldovenească). Academia Română, Memoriile Secțiilor ştiințifice, XXV (2002): 85-116.

Ionesi, L., Ionesi, B., Roşca, V., Lungu, A. \& Ionesi, V., 2005, Sarmațianul mediu şi superior de pe Platforma Moldovenească. Ed. Academiei Române, Bucureşti, $558 \mathrm{p}$.

Jeanrenaud, P., 1961, Contribuții la geologia Podişului Central Moldovenesc. Analele Ştiințifice ale Universității „Al. I. Cuza” Iaşi, secțiunea II (Ştiințe Naturale), seria b, Geologie-Geografie, VI (2): 417-432.

Jeanrenaud, P., 1971, Harta geologică a Moldovei Centrale dintre Siret şi Prut. Analele Ştiințifice ale Universității „Al. I. Cuza” Iaşi, secțiunea II (Ştiințe Naturale), seria b, Geologie-Geografie, XVII: 65-78.

Jurcsák, T., 1973, Răspîndirea mastodonților la vest de Munții Apuseni. Nymphaea, I: 313-341.

Jurcsák, T., 1983, Răspîndirea proboscidienilor în nordvestul României. Nymphaea, X: 65-85.

Koufos, G.D., 1986, Study of the Vallesian hipparions of the Lower Axios Valley (Macedonia, Greece). Geobios, 19 (1): 61-79.

Lapparent de B.F., Bour R. \& Perälä J., 2006, Morphological definition of Eurotestudo (Testudinidae, Chelonii): First part. Annales de Paléontologie, 92: 255-304.

Lungu, A., 1984, Ghipparionovaia fauna srednego Sarmata Moldavii copitnîe (Mlekopitaiuşcie), Chişinău, 159 p. 
Lungu, A., Jeanrenaud, P., Trelea, N. \& Simionescu, T., 1993, Les plus ancienes restes de Hipparion de la Moldavie, territoire d'entre le Prut et le Siret (Roumanie). Analele Ştiințifice ale Universității „Al. I. Cuza" Iaşi, secțiunea II (Ştiințe Naturale), seria b, Geologie-Geografie, XXXVIII-XXXIX: 103-109.

Lungu, A., Obadă, T., 2001, Contributions to the study of the Neogene representatives of Ordo Proboscidea (Mammalia) from Eastern Europe. The World of Elephants - International Congress, Abs., p. 119-121, Rome.

Macarovici, N., 1967, Kritischer Überblick über Hipparion im Neogen von Rumänien. Sitzungsberichten der Österreich Ackademie der Wissenschaften, Mathematische-naturwissenschaften Klasse, Abt. I, 176. Bd., 5 bis 7. Heft: 81-90.

Macarovici, N., 1973, Sur la faune à Hipparion du Méotien et du Pontien de la Roumanie. Studii şi cercetări de Geologie-Geografie-Biologie, seria Geologie-Geografie, 2: 79-84.

Macarovici, N., Paghida, N., 1966, Flora şi fauna din Sarmațianul superior de la Păun-Iaşi. Analele Universității Bucureşti, Geologie-Geografie, XV (1): 67-81.

Mazo A..V., 1996, Gomphotheres and mammutids from the Iberian Peninsula. In The Proboscidea. Evolution and Palaeoecology of Elephants and Their Relatives (Shoshani, J., Tassy, P., Eds.), $2^{\text {nd }}$ ed., New York, 472 p.

Nikolov, I., 1971, Novi predstaviteli na rod Hipparion $\mathrm{v}$ Bulgaria. Izv. Geologic Institut, Series Paleontologie, 20: 107-122.

Rădulescu, C., Ştiucă, E., Brustur, T. \& Zaharia, S., 1995, Neogene mammalian fauna from the bend zone of the East Carpathians. Romanian Journal of Stratigraphy, 76 (6): 19-23.

Rögl, F., 1999, Circum-Mediterranean Miocene Paleogeography. In Land Mammals of Europe (Rössner G.E., Heissig K., Eds.), Verlag Dr. Friedrich Pfeil, München, p. 39-48.

Saraiman, A., 1966, Mastodon longirostris Kaup găsit în formațiunile meoțiene, din podişul Central Moldovenesc. Analele ştiințifice ale Universității „,Al. I. Cuza“ din Iaşi (serie nouă), Secțiunea II (Ştiințe naturale), b. Geologiegeografie, XII: 123-131.
Săndulescu, M., 1984, Geotectonica României. Ed. Tehnică, Bucureşti, $335 \mathrm{p}$.

Săndulescu, M., 1994, Overview on Romanian geology. ALCAPA II, Geological evolution of the AlpineCarpathian-Pannonian system. Romanian Journal of Tectonics and Regional Geology, 75 (2): 3-15.

Schlesinger G., 1922, Die Mastodonten der Budapester Sammlungen. (Untersuchungen über Morphologie, Phylogenie, Ethologie und Stratigraphie europäischer Mastodonten. Geologica Hungarica, Series Geologica, 2 (1): 1-284.

Shoshani, J., Tassy, P. (Eds.), 1996, The Proboscidea. Evolution and Palaeoecology of Elephants and Their Relatives ( $2^{\text {nd }}$ ed.), New York, $472 \mathrm{p}$.

Simionescu, T., Trelea, N, 1991, La révision de certaines restes de Cervidés du Sarmatien de Păun (Dép. Iaşi). Analele Ştiințifice ale Universității „Al. I. Cuza” Iaşi, secțiunea II (Ştiinţe Naturale), seria b, Geologie, XXXVII: 31-36.

Steininger, F.F., Rabeder, G. \& Rögl, F., 1985, Land Mammal Distribution in the Mediterranean Neogene: A Consequence of Geokinematic and Climatic Events. In Geological Evolution of the Mediterranean Basin (Stanley D.J., Wezel F.-C., Eds.), Springer Verlag, Berlin, p. 559-571.

Steininger, F.F., Berggren, W.A., Kent, D.V., Bernor, R.L., Sen, S. \& Agusti, J., 1996, Circum-Mediterranean Neogene (Miocene and Pliocene) Marine-Continental Chronologic Correlations of European Mammal Units. In The Evolution of Western Eurasian Neogene mammal Faunas, (Bernor, R.L., Fahlbusch, V., Mittmann, H.-W., Eds.), Columbia University Press, New York, p. 7-46.

Țabără, D., 2006, Studiul palinologic al Basarabianului şi Chersonianului din Platforma Moldovenească Unpublished $\mathrm{PhD}$ thesis abstract, Universitatea "Al. I. Cuza", Iaşi, 43 p.

Țabără, D., Olaru, L., 2004, Contributions à l'étude palynologique des argiles du Basarabien supérieur de Şcheia. Acta Palaeontologica Romaniae (Codrea V., Petrescu I., Dica, P., Eds.), IV: 485-492. 
PLATE I
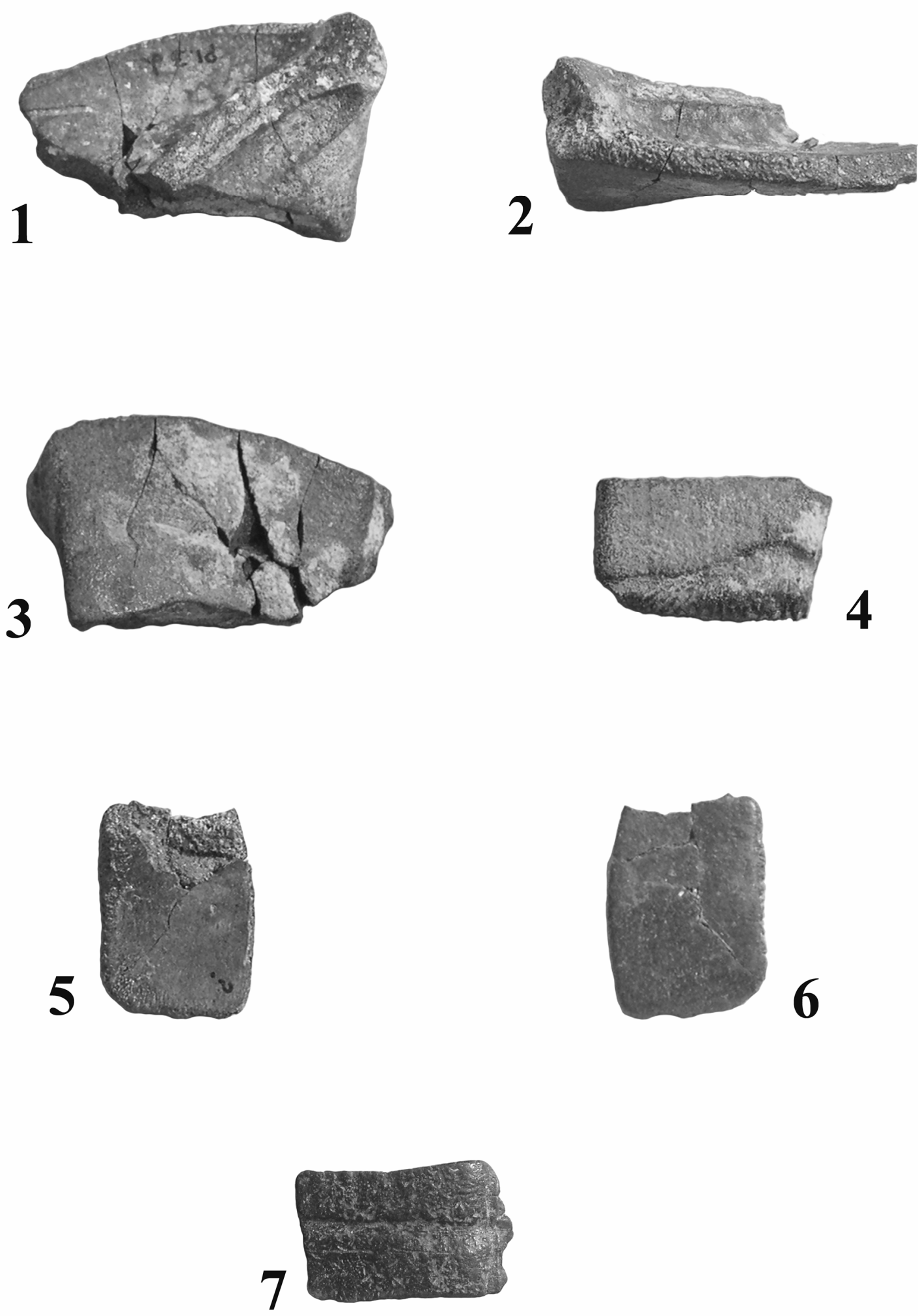

PLATE I Testudinidae indet. (small to medium size).

Fig. 1. Right $P l$ 3, inner view,

Fig. 2. Idem, lateral view,

Fig. 3. Idem, outer view,

Fig. 4. ? Left hypoplastron fragment,

Fig. 5-6. ?Pl with strong rolling marks, inner and outer view,

Fig. 7. Lleft Pl 6 fragment, outer view. Scale bar: $40 \mathrm{~mm}$ 
PLATE II
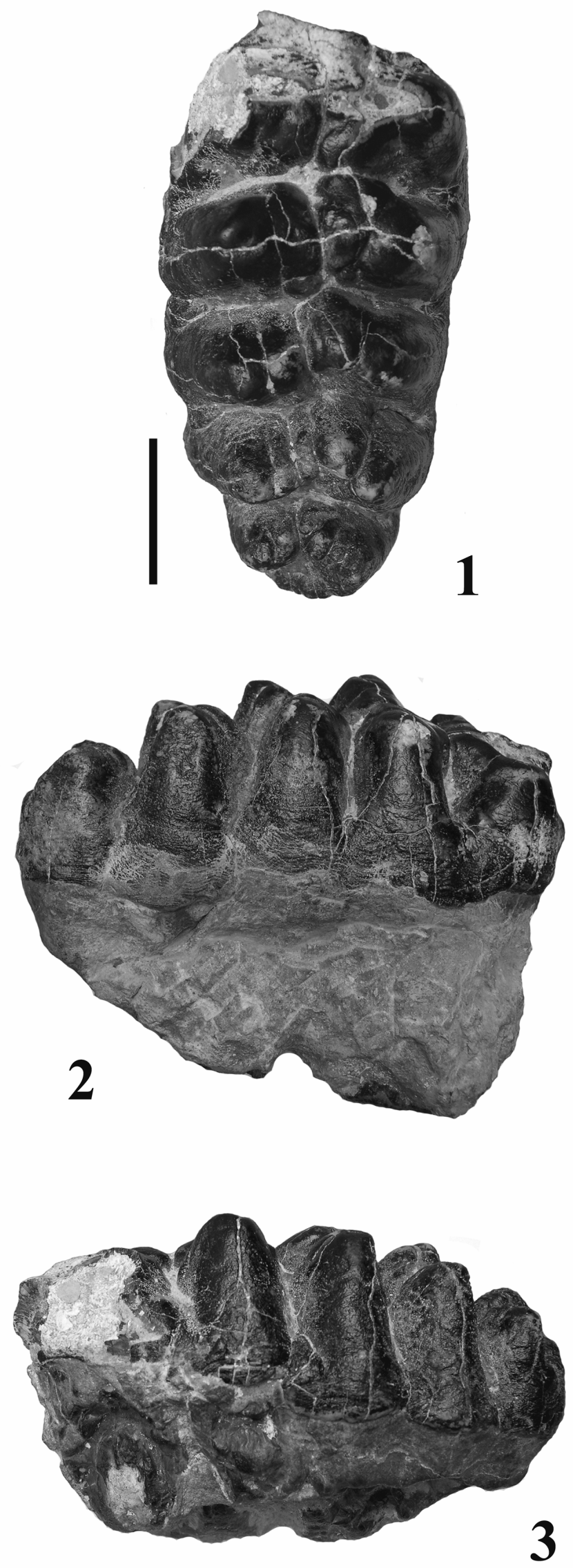

PLATE II Tetralophodon longirostris, right M3.

Fig. 1. Crown view

Fig. 2. Inner view

Fig. 3. Outer view. Scale bar: $40 \mathrm{~mm}$

Studia UBB, Geologia, 2007, 52 (2), 19 - 28 
PLATE III
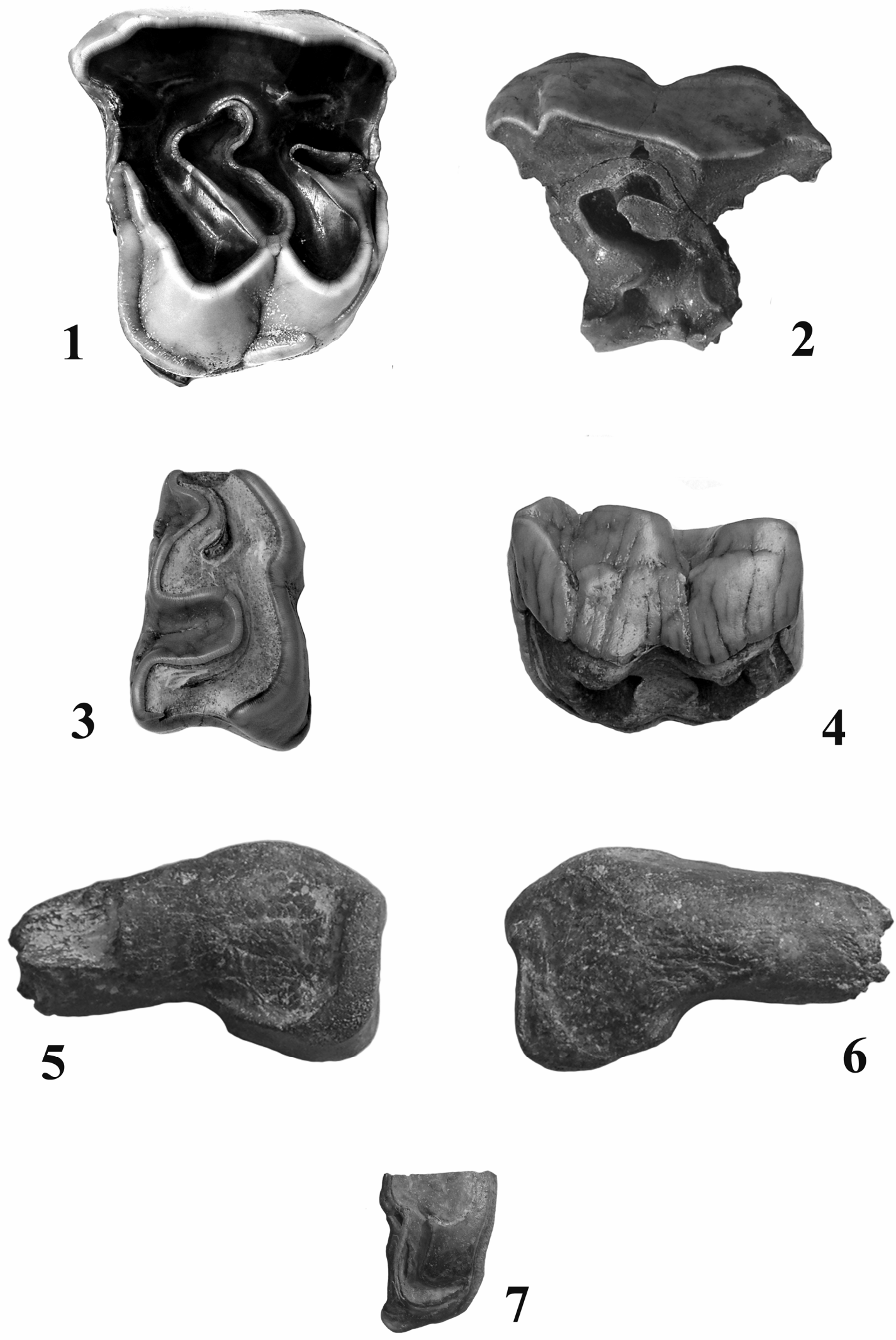

PLATE III Aceratherium incisivum.

Fig. 1. Left P4, crown view

Fig. 2. Left M2 fragment, crown view

Figs. 3-4. Right $p 3$, crown and inner views

Figs. 5-6. Left? Mc V, lateral views

Fig. 7. Lover? premolar fragment, abraded by rolling, crown view. Scale bar: $40 \mathrm{~mm}$ 
PLATE IV
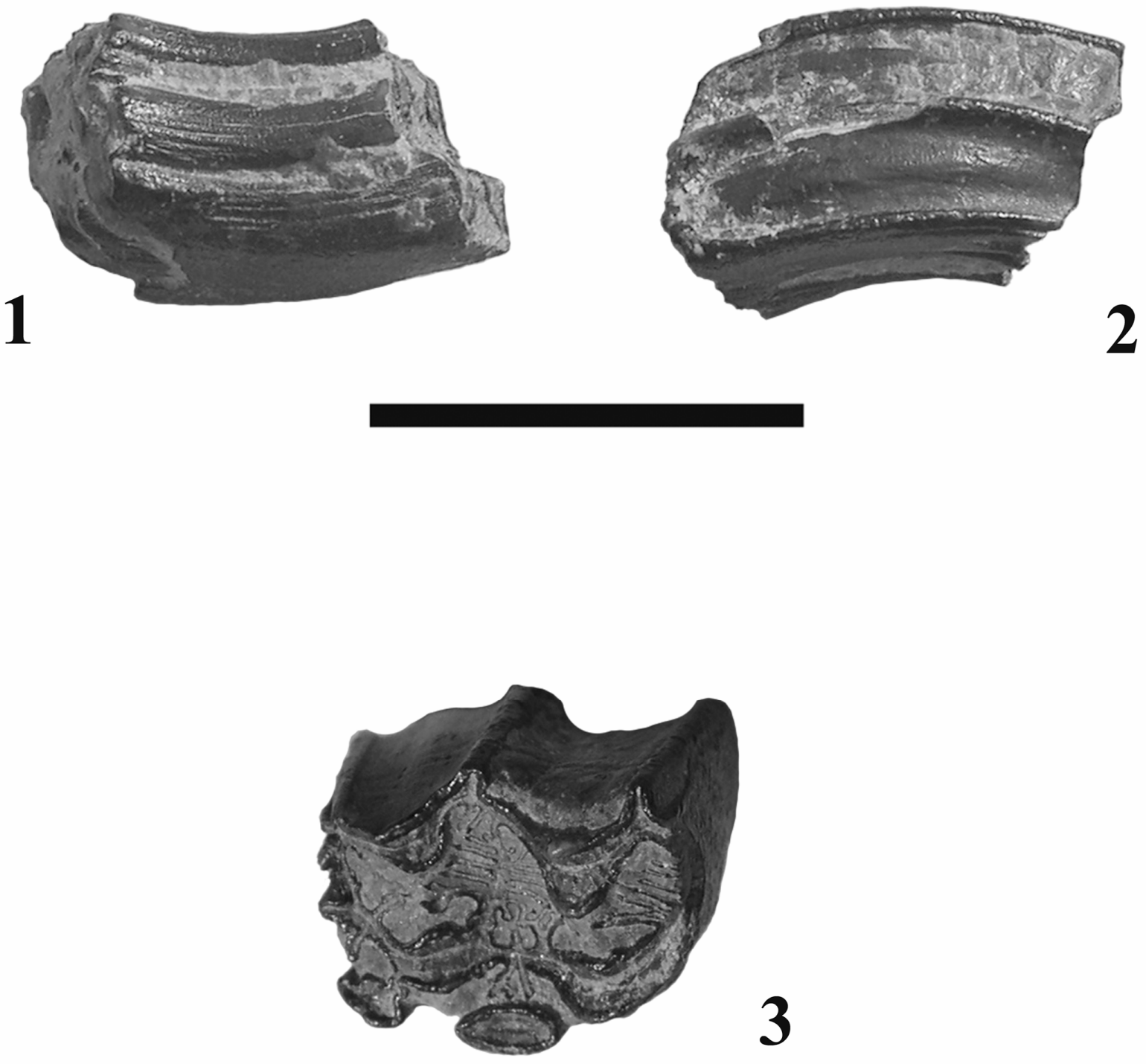

3

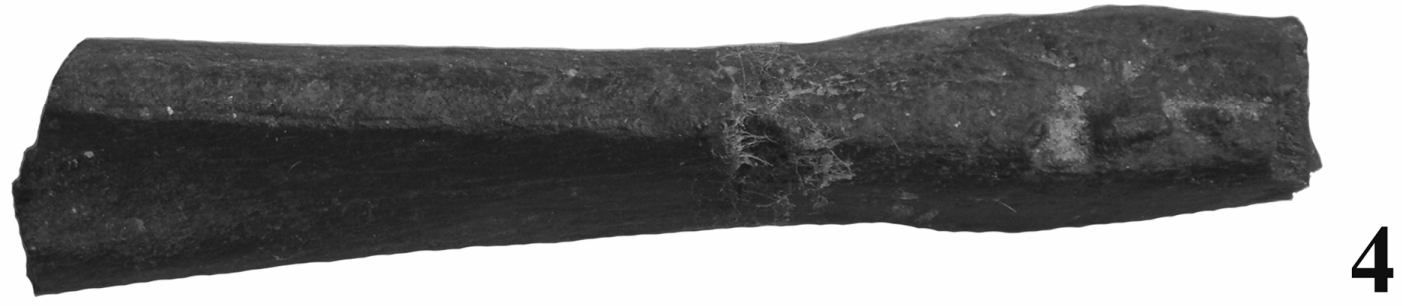

PLATE IV Hippotherium sp. (cf. Hippotherium primigenium), right M 3.

Figs. 1-2. Inner and outer views

Fig. 3. Crown view. ? Lagomerycinae (Lagomeryx flerovi - size), tibia diaphysis fragment

Fig. 4. ? Lagomerycinae (Lagomeryx flerovi-size), tibia diaphysis fragment. Anterior view. Scale bars: 40 